\title{
Fat-1 transgenic cattle as a model to study the function of $\omega-3$ fatty acids
}

Tao Guo ${ }^{1,2}$, Xin F Liu', Xiang B Ding ${ }^{1}$, Fei F Yang ${ }^{1}$, Yong W Nie', Yu J $\mathrm{An}^{2}$ and Hong Guo ${ }^{1 *}$

\begin{abstract}
$\omega-3$ polyunsaturated fatty acids have been shown to play an important role in health. Enriched with $\omega-3$ polyunsaturated fatty acids modulate expression of a number of genes with such broad functions as cell proliferation, growth and apoptosis and cell signaling and transduction, these effects, seem to regulate coronary artery disease, hypertension, atherosclerosis, psychiatric disorders and various cancer. In this context, fat-1 transgenic cattle was designed to convert $\omega-6$ to $\omega-3$ fatty acids could form an ideal model to study the effect of $\omega$-3 fatty acids on the above functions. This study focuses on the total genomic difference of gene expression between fat-1 transgenic cattle and wild-type using cDNA microarrays, several genes were found to be overexpressed or suppressed in transgenic cattle relative to wild-type, these discrepancy genes related with lipid metabolism, immunity, inflammation nervous development and fertility.
\end{abstract}

Keywords: fat-1, transgenic cattle, $\omega-3$ fatty acids, gene expression, gene function

\section{Introduction}

$\omega-3$ fatty acids can exert a wide range of effects on cell function. In addition to being a source of energy, these fatty acids can act as determinants of the physiochemical properties of cell membranes, as substrates for the production of signaling molecules or functioning mediators, and as modulators in the regulation of gene expression. Therefore, $\omega-3$ fatty acids can profoundly affect the physiological activity and pathological process through different mechanisms.

Mammals cannot convert $\omega-6$ to $\omega-3$ fatty acids automatically. Fat- 1 transgenic mice showed that increased content of $\omega-3$ fatty acids, especially ALA, EPA, DHA, in addition, the ratio of $\omega-6 / \omega-3$ fatty acids is dramatically decreased in various kinds of tissues [1]. Fat-1 transgenic animal model offers an opportunity for investigating the biological functions of $\omega-3$ fatty acids and the importance of the ratio of $\omega-6 / \omega-3$ in various physiological processes and diseases. The transgenic mice was found to be normal and healthy and many generations of transgenic mouse lines have been examined and their tissue fatty acid profiles showed consistently high

\footnotetext{
* Correspondence: guohong882003@yahoo.com.cn

'Department of Animal Science, Tianjin Agriculture University, Tianjin 300384, China

Full list of author information is available at the end of the article
}

levels of $\omega-3$ fatty acids, indicating that the transgene is transmittable [2]. $\omega-3$ fatty acids have many important actions not only by themselves but also by giving raise to various biologically active compounds. $\omega-3$ fatty acids play a significant role in various diseases and especially in cancers and neurological/psychiatric disorders [2-5].

Due to the polyunsaturated fatty acids modulated gene transcription. Considering this, we utilize the cDNA microarray that is a powerful method that allows the expression of thousands of genes to be determined simultaneously. The studies of gene expression were regulated by $\omega-3$ fatty acids mostly on specific tissue in vitro or vivo $[2,6]$, there are rare reports the genomic expression influenced by $\omega-3$ fatty acids, specifically in fat- 1 transgenic cattle. Here we take the fat- 1 transgenic cattle as model to study the change of genomic expression influenced by the increased $\omega-3$ fatty acids and decreased ratio of $\omega-6 / \omega-3$ fatty acids in the body. Thousands of discrepancy genes generated from this experiment, we choose the representative dates to analysis and delineate the exact molecular mechanism of functions of $\omega-3$ fatty acids.

\section{Materials and method \\ Fat-1 transgenic cattle}

Cattle were engineered to carry fat-1 gene from Caenorhabditis elegans which can add a double bond into an 
unsaturated fatty acid hydrocarbon chain and convert $\omega$ 6 to $\omega-3$ fatty acids. The transgenic cattle were provided by Inner Mongolia University, life science institute.

\section{RNA isolation and analysis}

RNA was extracted from whole blood by TRIzol extraction protocol. To ensure the quality, total RNA was quantified by UV spectrophotometry, and the purity of total RNA was assessed by $1 \%$ agarose.

\section{Purification of RNA and CDNA synthesis}

If the purity of total RNA was not very well, it will be influence the efficiency of probe labeling and the result of the chip hybridization. RNA was purified by using a RNeasy ${ }^{\circledR}$ Mini Kit (QIAGEN, Germany), following the manufacturer's recommended protocol.

One-step of cDNA synthesis. The reaction were performed with 11.5 ul of RNA mixture ( 2 ug of purified RNA, 5 ul of T7 promotor primer, RNase-free Water add to $11.5 \mathrm{ul}$, then incubation for $10 \mathrm{~min}$ at $65^{\circ} \mathrm{C}$, icebath for $5 \mathrm{~min}$ to denaturation), $4 \mathrm{ul}$ of $5 \times$ First strand buffer, 2 ul of $0.1 \mathrm{M}$ DTT, 1 ul of $10 \mathrm{mM}$ dNTP mix, 1 ul of MMLV RT, $0.5 \mathrm{ul}$ of RNase out. The reaction condition was used lid temperature at $65^{\circ} \mathrm{C}$, incubation for $2 \mathrm{~h}$ at $40^{\circ} \mathrm{C}, 65^{\circ} \mathrm{C}$ for $15 \mathrm{~min}, 4^{\circ} \mathrm{C}$ for $5 \mathrm{~min}$.

\section{CRNA synthesis labeling with aaUTP and purification of CRNA}

First, transcription mixture $(60 \mathrm{ul})$ including $5.7 \mathrm{ul}$ of RNase-free water, 20 ul of $4 \times$ Transcription buffer, 16 ul of NTP $(10 \mathrm{mM}), 6 \mathrm{ul}$ of $0.1 \mathrm{M} \mathrm{DTT}, 6.4 \mathrm{ul}$ of $50 \%$ PEG, 4 ul of aa-UTP( $25 \mathrm{mM}), 0.5 \mathrm{ul}$ of RNase OUT, 0.6 ul of Inorganic Pyrophosphatase, $0.8 \mathrm{ul}$ of T7 RNA Polymerase. Afterward, 20 ul of cDNA was added into $60 \mathrm{ul}$ of transcription mix and mixing. The reaction condition was used lid temperature at $60^{\circ} \mathrm{C}$, incubation for $2 \mathrm{~h}$ at $40^{\circ} \mathrm{C}$.

cRNA was purified by using a RNeasy ${ }^{\circledR}$ Mini Kit(QIAGEN, Germany), following the manufacturer's recommended protocol.

\section{Fluorescence labeling and purification}

To concentrate the $4 \mathrm{ug}$ of cRNA which was above -mentioned to $6.6 \mathrm{ul}$ and add $10 \mathrm{ul}$ of DMSO, 3.4 ul of $0.3 \mathrm{M} \mathrm{NaHCO} 3(\mathrm{pH} 9.0)$ and mixing. $\mathrm{Cy} 3$ was added into the $20 \mathrm{ul}$ of mixture, incubation for $1 \mathrm{~h}$ at $25^{\circ} \mathrm{C}$. Finally, $10 \mathrm{ul}$ of $4 \mathrm{M}$ Hydroxylamine was added and incubation for $15 \mathrm{~min}$ at $25^{\circ} \mathrm{C}$. Fluorescence labeling cRNA also need purification, the method as same as the purification of cRNA, which was above -mentioned.

\section{Hybridization $(4 \times 44 \mathrm{~K}$ microarrays)}

The purified Cy3 cRNA demand to fragmentation before the hybridization, the reaction $(55 \mathrm{ul})$ was performed with $875 \mathrm{ng}$ of Cy3 cRNA, 11 ul of $10 \times$ Blocking Agent, 2.2 ul of $25 \times$ Fragmentation Buffer, Nuclease-free water added to $55 \mathrm{ul}$, incubation for 30 min at $60^{\circ} \mathrm{C}$ to fragmentation. $45 \mathrm{ul}$ of $2 \times$ GEx Hybridization Buffer was added into the cRNA fragmentation. $100 \mathrm{ul}$ mixture was dropped onto the center of the array surface and then covered with a coverslip without any bubbles. The slides were placed into a sealed cassette to hybridize at $65^{\circ} \mathrm{C}$ water bath for $17 \mathrm{~h}$.

After hybridization, the microarray slides were washed once with $2 \times$ SSC, $0.1 \%$ sodium dodecyl sulfate (SDS) at $42^{\circ} \mathrm{C}$ for $4 \mathrm{~min}$, once with $0.1 \times \mathrm{SSC}, 0.1 \% \mathrm{SDS}$ at room temperature for $10 \mathrm{~min}$ and three times with 0.1 $\times \mathrm{SSC}$ at room temperature for $1 \mathrm{~min}$. The microarray slides were then washed with distilled water and spin dried. Hybridized slides were scanned at $5 \mu \mathrm{m}$ using an Agilent chip Scanner. The scanner could scan with $100 \%$ and $10 \%$ PMT automatically, two results were combined use Agilent software automatically.

\section{Result and analysis}

Fat-1 transgenic cattle and wild-type cattle have 43653 discrepancy expressed transcripts according to the Agilent software. It will be waste abundant time and energy to analysis all database, and some databases are meaningless to analysis, so this study we choose differentially expressed genes of $\mathrm{p}$-value $\leq 0.05$ and $\mathrm{fc} \geq 1$ (Table 1).

In our study fat- 1 transgenic cattle convert $\omega-6$ fatty acids into $\omega-3$ fatty acids and decrease the ratio of $\omega-6 /$ $\omega-3$ fatty acids (dates not shown), the change composition of polyunsaturated fatty acids can effects on gene expression, some genes are up regulation and some genes are down regulation, and then affect the physiological activity and pathological process through different mechanisms.

\section{$\omega-3$ fatty acids on lipid metabolism}

Fat- 1 transgenic cattle enriched $\omega-3$ fatty acids, $\omega-3$ fatty acids play a major role in the regulation of several genes involved in fatty acid metabolism. There had been reported that the influenced by $\omega-3$ fatty acids on lipolytic and lipogenic gene expression [7-9]. Hyperlipidemia is often associated with insulin resistance, coronary artery disease, hypertension [3-5,10]. Decreased $\omega-6 / \omega-3$ ratio in the fat- 1 mouse can enhance glucose tolerance, independent of changes in mitochondrial content [11]. Decreased in both mitochondrial content and intrinsic ability of mitochondrial to oxidize fatty acids, can contribute to lipid accumulation and development of insulin resistance [12,13], overexpression of carnitine palmitoyltransferase (CPT-1) and peroxisome proliferator activated receptor $\gamma$ (PPAR- $\gamma$ ) increasing fatty acids oxidation and improving insulin sensitivity $[14,15]$. In our study, the expression of CPT- 1 and PPAR- $\gamma$ were 
Table 1 Gene expression that either upregulated or downregulated in the whole genome of fat-1 transgenic cattle ( $p$ value $<0.05$ and $\mathrm{fc} \geq \mathbf{1}$ )

\begin{tabular}{|c|c|c|}
\hline Genbank Accession & Gene name & Fold change \\
\hline \multicolumn{3}{|l|}{ Metabolism } \\
\hline NM_177494 & carnitine palmitoyltransferase 1 & 1.635675 \\
\hline NM_174530 & cytochrome P450, family 2, subfamily E, polypeptide 1 & 3.129168 \\
\hline NM_001100366 & cytochrome P450, family 2, subfamily S, polypeptide 1 & 1.085825 \\
\hline NM_001099367 & cytochrome P450, family 3, subfamily A, polypeptide 4 & 1.0726473 \\
\hline NM_001046391 & cytochrome P450, family 4, subfamily F, polypeptide 3 & 1.021228 \\
\hline NM_174810 & ATPase, $\mathrm{H}+$ transporting, lysosomal 31 kDa, V1 subunit E1 & 1.0310035 \\
\hline NM_174717 & ATP synthase, $\mathrm{H}+$ transporting, mitochondrial Fo complex, subunit F6 & 1.0874296 \\
\hline NM_001083636 & peroxisome proliferator activated receptor & 1.1880234 \\
\hline AB257751 & low density lipoprotein receptor-related protein 5 & -1.1805074 \\
\hline NM_001077843 & low density lipoprotein receptor-related protein 4 & -1.5911577 \\
\hline \multicolumn{3}{|l|}{ Immunity } \\
\hline XM_001250583 & Indoleamine 2, 3-dioxygenase & 2.0460057 \\
\hline XR_042605 & granulocyte-macrophage colony-stimulating-factor receptor $\alpha$ & 2.167638 \\
\hline NM_174358 & interleukin-2 receptor $\alpha$ & -2.3078954 \\
\hline NM_174093 & interleukin-1, beta & -2.8775382 \\
\hline NM_174086 & interferon- $\gamma$ & -2.1359362 \\
\hline NM_173923 & nterleukin-6 & -1.8120259 \\
\hline XM_591164 & interleukin-10 receptor $\alpha$ & -1.107485 \\
\hline XM_615064 & CD4 molecule & -1.19058 \\
\hline XM_001787801 & WC1 & -6.185475 \\
\hline \multirow[t]{2}{*}{ XM_593126 } & lymphocyte-activation gene 3 & -2.201507 \\
\hline & similar to Zeta-chain associated protein kinase $70 \mathrm{kDa}$ & -2.379626 \\
\hline NM_177493 & acetylserotonin O-methyltransferase & -2.1411839 \\
\hline NM_174589 & prostaglandin E receptor 4 & -1.1957332 \\
\hline NM_001166554 & prostaglandin E synthase 2 & -1.0895984 \\
\hline NM_001078151 & mature T-cell proliferation 1 & -1.0484107 \\
\hline BC142016 & T-cell receptor delta chain & -2.3310187 \\
\hline XM_603087 & T-cell acute lymphocytic leukemia 2 & -1.1402003 \\
\hline NM_001075374 & lymphocyte-specific protein 1 & -1.2811403 \\
\hline NM_001102073 & immunoglobulin-like domain containing receptor 2 & -1.6142586 \\
\hline NM_001076844 & lymphocyte cytosolic protein 2 & -1.2404228 \\
\hline NM_001034720 & lymphocyte cytosolic protein 1 & -1.0534877 \\
\hline \multicolumn{3}{|c|}{ Inflammation and cancer } \\
\hline NM_001101158 & cell adhesion molecule 1 & 10.783385 \\
\hline NM_001035468 & acireductone dioxygenase 1 & 2.893599 \\
\hline NM_001083481 & suppression of tumorigenicity 7 like & 1.1566072 \\
\hline NM_001035287 & serpin peptidase inhibitor & 7.2662635 \\
\hline NM_001083645 & RAS-like, family 10 , member $\mathrm{A}$ & 2.4159741 \\
\hline NM_001101092 & serine/threonine kinase 38 like & 1.0883793 \\
\hline XM_608304 & NLR family, pyrin domain containing 13 & 2.8275476 \\
\hline NM_174532 & DnaJ (Hsp40) homolog, subfamily B, member 6 & 1.0343608 \\
\hline NM_175804 & nuclear receptor subfamily 2 , group $F$, member 1 & 1.1831405 \\
\hline XM_613126 & chondroitin sulfate proteoglycan 4 & -2.4661286 \\
\hline NM_001024521 & TNF receptor-associated factor 7 & -1.182513 \\
\hline XM_594145 & L1 cell adhesion molecule & -2.0497224 \\
\hline XM_604945 & adenomatosis polyposis coli 2 & -2.1012108 \\
\hline XM_608123 & laminin, alpha 4 & -2.7227702 \\
\hline AB043995 & matrix metallopeptidase 3 & -2.013966 \\
\hline XM_597651 & matrix metallopeptidase 15 & -1.0679191 \\
\hline
\end{tabular}


Table 1 Gene expression that either upregulated or downregulated in the whole genome of fat-1 transgenic cattle (pvalue ?<? 0.05 and $\mathrm{fc} ? \geq ?$ ? 1) (Continued)

\begin{tabular}{|c|c|c|}
\hline NM_174112 & matrix metallopeptidase 1 & -1.0266808 \\
\hline XM_604345 & matrix metallopeptidase 16 & -1.1511999 \\
\hline XM_609577 & matrix metallopeptidase 20 & -1.0834453 \\
\hline NM_001075502 & nitric oxide synthase interacting protein & -1.027486 \\
\hline NM_001076799 & nitric oxide synthase 2 & -1.1507416 \\
\hline NM_174589 & prostaglandin E receptor 4 & -1.1957332 \\
\hline NM_174443 & prostaglandin E synthase & -1.0576057 \\
\hline NM_001166554 & prostaglandin E synthase 2 & -1.0895984 \\
\hline DV775423 & claudin 10 & -1.221211 \\
\hline XM_601963 & $\beta$-catenin & -2.1087096 \\
\hline XM_609364 & NF-kB & -1.7619956 \\
\hline NM_001102498 & NF-kB activating protein-like & -1.2362162 \\
\hline XM_582283 & Huntingtin interacting protein-1 & 2.2835305 \\
\hline NM_001159566 & transforming growth factor, beta receptor II & -1.1494738 \\
\hline NM_001035313 & transforming growth factor beta 1 induced transcript 1 & -1.560125 \\
\hline XM_001253071 & transforming growth factor, beta receptor III & -1.0382366 \\
\hline NM_001101910 & tumor protein p53 binding protein 1 & -1.1203252 \\
\hline NM_174201 & tumor protein $\mathrm{p} 53$ & -1.1353312 \\
\hline NM_001076401 & gamma-glutamyltransferase 7 & -2.7013438 \\
\hline \multicolumn{3}{|c|}{ Nervous development } \\
\hline XM_588574 & protocadherin gamma subfamily $A, 6$ & 4.1054792 \\
\hline XM_001254336 & protocadherin gamma subfamily $A, 8$ & 3.6014705 \\
\hline NM_001102513 & protocadherin gamma subfamily $B, 4$ & 1.5915743 \\
\hline XM_870459 & protocadherin gamma subfamily A, 9 & 3.789133 \\
\hline BC103033 & potassium channel, subfamily K, member 10 & 1.2212783 \\
\hline XM_001253926 & Olfactory receptor $13 \mathrm{H} 1$ & 4.0936475 \\
\hline NM_001076371 & SEPTIN5 & 2.3829544 \\
\hline XM_608747 & nucleoredoxin-like 2 & 6.2915673 \\
\hline XM_001788280 & semaphorin 5B & -3.1176894 \\
\hline \multicolumn{3}{|l|}{ Fertility } \\
\hline NM_001034205 & Calmegin & 2.228811 \\
\hline XM_608786 & SRY (sex determining region Y)-box 8 & 1.8772229 \\
\hline NM_001076057 & EF-hand calcium binding domain 6 & -2.55162 \\
\hline
\end{tabular}

up-regulation. It is important that the CYP (including CYP2E1, CYP2S1, CYP3A4, CYP4F3) encodes a member of the cytochrome P450 superfamily of enzymes that involved in the polyunsaturated fatty acids oxidation were upregulated.

To decrease the content of very low-density lipoprotein (VLDL) is benefit to coronary artery disease, hypertension. $\omega-3$ fatty acids suppress triglyceride synthesis, VLDL secretion, and serum triglycerides $[4,16]$. Decrease the VLDL level can through two mechanisms involved in $\omega-3$ fatty acid specific control of VLDL synthesis. First, decrease the VLDL expression directly, such as suppress the expression of low density lipoprotein receptor in transgenic cattle. Second, suppression of ApoCIII transcription, PPAR competes with HNF4 for binding the ApoCIII promoter. PPAR expression was increased in transgenic cattle $[17,18]$. $\omega-3$ fatty acids protect against insulin resistance, coronary heart disease, hypertension by lowering triglyceride explained by the inhibition of hepatic lipogenesis and the simultaneous stimulation of mitochondrial fatty acid oxidation.

\section{$\omega-3$ fatty acids on Immunity}

$\omega-3$ fatty acids has beneficial effects on immune function [19]. $\omega-3$ fatty acids regulate the immuniy through suppress the T-lymphocyte proliferation. T-lymphocyte proliferation has been shown to be inhibited in vitro by an increased concentration of free fatty acids via an eicosanoid-independent mechanism [20]. The T-lymphocyte regulates an immune response by responding to antigen, then produce cytokines. There are three major subsets of T-lymphocytes, Th (helper T cells), Tc (cytotoxic $\mathrm{T}$ cells), Treg (regulatory $\mathrm{T}$ cells). Th and Tc 
express the CD4 and CD8 receptors respectively. The $\mathrm{CD} 4^{+}$T-lymphocyte can further be classified as either a Th-1 or Th-2 type cell depending on the types of cytokines it produces. The Th-1 type produces primarily interleukin-2 (IL-2) and interferon- $\gamma$ (IFN- $\gamma$ ) which upregulates cell mediated immunity. The Th- 2 type produces primarily IL-4, 5, 6, 10 and 13 which upregulates humoral or antibody mediated immunity via activation of B-cells and macrophages. We found that the expression of CD4 was decreased in transgenic cattle, and it stand to reason that the expression level of IL-2 and IFN- $\gamma$ were decreased, in addition, the expression of IL6 and IL-10 were decreased.

It is widely known that granulocyte-macrophage colony-stimulating-factor (GM-CSF) combination with cytokines to differentiate human peripheral blood monocytes into potent $\mathrm{T}$ cell-stimulatory cells and also has been involved in the spontaneous differentiation of human monocyte precursors into macrophages, by enhancing their survival $[21,22]$. GM-CSF is promote the differentiation of human blood monocytes into dendritic cell(DC) and that the number of DC achieved in the presence of GM-CSF alone, but not in combination with IL-4, correlates with the extent of GM-CSF receptor $\alpha$ expression [23]. The expression level of GMCSFR $\alpha$ is down regulated in transgenic cattle.

A sequence in transgenic cattle which similar to ZAP70 (Zeta-chain associated protein kinase $70 \mathrm{kDa}$ ) is down-regulation. ZAP-70, a cytoplasmic tyrosine kinase mainly expressed in T cells, and it plays a role in T-cell development and lymphocyte activation [24-27]. In rodents, it has been shown that stimulation through the TCR/CD3 complex is associated with reduced IL-2 production and subsequent proliferation [28]. Loss of ZAP70 activation in response to TCR/CD3 receptor stimulation and subsequent suppression of IL-2 production [29].

Indoleamine 2, 3-dioxygenase (IDO2), which is the rate-limiting enzyme for tryptophan catabolism, may play a critical role in various inflammatory disorders [30]. IDO2 may be important to sustain immune escape, IDO2 seems to block the proliferation of alloreactive T lymphocytes through arrest in the G1 phase of the cell cycle [31-33]. The expression of IDO2 is increased in transgenic cattle.

Regulatory T cells (Treg) play an important role in maintain of homeostasis of the immune system capable of suppressing other immune responses in vitro and/or in vivo. The cattle $\mathrm{CD} 4^{+} \mathrm{CD} 25^{\text {high }} \mathrm{Foxp}^{+}$and $\mathrm{CD} 4$ ${ }^{+} \mathrm{CD} 25^{\text {low }}$ Foxp $3^{+} \mathrm{T}$ cells do not function as Treg ex vivo. This indicates that the bovine immune system may be governed by different regulatory mechanisms as compared to rodents and humans. In the bovine immune system a role for monocytes has been suggested in the control of $\gamma \delta \mathrm{T}$ cell responses [34], probably mediated by IL-10 secretion [35]. The bovine Treg function appears to reside in the $\gamma \delta \mathrm{T}$ cell population, more precisely in the $\mathrm{WC} 1.1^{+}$and the $\mathrm{WC} 1.2^{+}$subpopulation, major populations present in blood of cattle [36], in this study the expression of WC1 in transgenic cattle is down regulation. Expression of LAG3 in human $\mathrm{CD} 4^{+} \mathrm{T}$ cells and found that LAG3 identifies a discrete subset of CD $4^{+} \mathrm{CD} 25^{\text {high }}$ Foxp $3^{+} \mathrm{T}$ cells. CD $4^{+} \mathrm{CD} 25^{\text {high }}$ Foxp3 ${ }^{+} \mathrm{LAG}^{+} \mathrm{T}$ cells are functionally active cells that release the immunosuppressive cytokines IL- 10 and TGF- $\beta 1$ [37]. Nevertheless, the cattle $\mathrm{CD} 4^{+} \mathrm{CD} 25^{\text {high }}$ Foxp $3^{+} \mathrm{T}$ cells do not function as Treg ex vivo[36], lower expression of LAG3 in transgenic cattle whether influence the immune should be further study.

Acetylserotonin O-methyltransferase (ASMT) is the enzyme involved in the last step of melatonin synthesis. Melatonin is a powerful antioxidant molecule involved in the protection of nuclear and mitochondrial DNA and in the regulation of circadian seasonal rhythms and immune function [38]. It is produced and secreted predominantly by the pineal gland. The proportions of ASMT-immunoreactive cells successively decreased in the pineocytoma [39]. Lower expression of ASMT in transgenic cattle may affect the melatonin synthesis and then influence the immune function.

Feeding purified EPA and DHA significantly reduced spleen lymphocyte proliferation, natural kill cell activity and PGE2 production in nonautoimmune prone mice [40]. It is consistent with the result that natural kill cells activity and the expression of prostaglandin E synthase are reduced in transgenic cattle.

\section{(-3 fatty acids on inflammation and cancer}

A large number of epidemiological studies and data in rodents implicate polyunsaturated fatty acid related with cancer particularly colon, breast, and prostate cancer $[5,41,42]$. They are complex diseases that are affected by both genetic and environmental factors. There have been advanced to explain that fatty acid composition effects on membrane fluidity, cell signaling, hormone imbalance, and prostanoid synthesis [41-43]. Fatty acid effects on cell growth, differentiation, metabolism, and the production of eicosanoids, cytokines, and adhesion molecules are all likely to contribute to cancer cell growth.

The generation of proinflammatory cytokines, eicosanoids, and growth factor agonists and antagonists at the site of injury contributes to atherosclerosis [44]. To decrease the eicosanoid, cytokine, and adhesion molecule production is benefit to control the atherosclerosis process. The production of adhesion molecules (VCAM1) from cultured endothelial cells is suppressed by $\omega-3$ fatty acids [45]. Adhesive interactions between 
leucocytes and cellular or extracellular components of tissues are involved in inflammatory or immunological response mechanisms. Adhesion molecules direct the leucocyte-endothelium interactions, transendothelial migration of leucocytes and leucocyte trafficking in general [46]. However, our date showed that expression of VCAM-1 in transgenic cattle is higher than wild-type cattle.

Eicosanoid is promote the tumourgenesis, which produced by COXs and LOXs to catalyze Amino acid or EPA. The antiproliferative effects of $\omega-3$ fatty acids in cancers is inhibit the expression of cyclooxygenase 2 (COX2), at least partly [47]. However, the change of COX2 expression level is not detected in our data. To decrease the COX2 expression also can by regulate other genes indirectly, such as nitric oxide (NO). NO activates COX2 expression, the effect of DHA on COX2 could be to decrease $\mathrm{NO}$ indirectly. Narayanan et al had shown that treatment of human colon cancer cells with DHA downregulates inducible NO synthase [48]. NO also can cause cell damage in inflammation process, therefore, it is possible that sustained high levels of NO generated by iNOS can produce lead to tumor initiation and promotion various kinds of damage $[49,50]$. DHA could indeed induce cancer cell death via down-regulation of iNOS expression and/or by modulating sets of genes involved in apoptosis and differentiation [51]. Ntric oxide synthase was decreased in transgenic cattle in our study.

Arachidonic acid (AA) which is released from membrane phospholipids together with diacylglycerol during signal transduction activates the transcription factor or nuclear factor NF-kB, which then transmigrates into the cell nucleus and induces a number of the inflammatory genes, such as COX2, cytokines, and adhesion molecules. Inhibit of NF-kB signaling is contribute to the anti-inflammatory actions of DHA $[52,53]$. The expression NF-kB activation induced by arachidonic acid is decrease in transgenic cattle, in turn, down-regulates the transcription of genes regulating the inflammatory response (cytokines, chemokines, cell adhesion molecules). Berger A et al consistent with the result that hepatic NF-kB gene expression was downregulated by DHA [54].

Chondroitin sulfate proteoglycan 4 (CSPG4), also known as high Molecular Weight- Melanoma Associated Antigen, is a cell surface proteoglycan which has been recently shown to be expressed not only by melanoma cells, but also expressed by basal breast carcinoma, squamous carcinoma of the head and neck, mesothelioma, pancreatic carcinoma, some types of renal cell carcinoma, chordoma, and chondrosarcoma cells, however, its restricted distribution in normal tissues and cells [55]. So lower expression of CSPG4 in transgenic cattle may be a signal of reduce the risk of suffer from various types of cancer. Furthermore, there have other genes related with cancer showed in Table 1. There had reported that fat- 1 mice with elevate $\omega-3$ fatty acid is suppressed various tumorigenesis [56-59].

Huntingtin interacting protein-1 (HIP1) is known to be associated with the N-terminal domain of huntingtin. Overexpression of HIP1 induced cell death through caspase-3 activation in immortalized hippocampal neuroprogenitor cells [60], HIP1 overexpression was also found in several primary epithelial tumors including breast, ovarian, prostate, lung and colon, and its expression negatively correlated with survival in men with prostate cancers [61]. The expression of HIP1 in transgenic cattle is increased.

\section{$\omega-3$ fatty acids on nervous development and neurologic disease}

PUFAs have many important actions not only by themselves but also by giving raise to various biologically active compounds. PUFAs play a significant role in various diseases and especially in cardiovascular and neurological/psychiatric disorders [62]. Enrich the $\omega-3$ fatty acids alter the composition of membranes. Alteration in the cellular architecture along with alterations in molecular composition of membranes might influence a wide range of brain functions: stabilization of axons and dendrites, cell shape, polarity, neural plasticity, vesicle formation and transport. Diet with high DHA slowed the progression of Alzheimer's disease (AD) in mice. Specifically, DHA cut the harmful brain plaques that mark the disease [62-64]. DHA protected against damage to the «synaptic» areas and enabled mice to perform better on memory tests [2]. The observation that $\omega-3$ fatty acids, affect expression levels of a number of genes in brain opens the way toward understanding the role of these fatty acids in the function of central nervous tissue.

The proteins encode by protocadherin gamma subfamily most likely play a critical role in the establishment and function of specific cell-cell connections in the brain, such as PCDHGA9, PCDHGA8, PCDHGB4, PCDHGA6 [65], so higher expression of this genes may beneficial to brain development. KCNK10 is probably an important ion channel to involve in the neuroprotection by tuning the level of resting potential, reducing the brain cell excitability and release of stimulative neurotransmitters. The expression of KCNK10 is increased when in the process of neuropathic pain and memory impaired [66]. The expression of KCNK10 in transgenic cattle is lower than wild-type. SEMA5B is involved in synapse elimination in hippocampal neurons. Overexpression of SEMA5B in hippocampal neurons results in a decrease in synapse number, however, depletion of endogenous SEMA5B using short hairpin RNA (shRNA) 
resulted in the exuberant formation and/or maintenance of synaptic connections, with a concomitant increase in the size of pre and postsynaptic densities [67], lower expression of this gene in transgenic cattle may increase the synaptic number and size in hippocampal neurons, and maybe increase the ability of learning and memory. Recent studies in fat-1 transgenic mice showed that increased brain DHA significantly enhances hippocampal neurogenesis as evidenced by an increase in the number of pro-liferating neurons and increased density of dendritic spines of CA1 pyramidal neurons in the hippocampus [68]. The study of fat- 1 transgenic mice had demonstrated that higher level of $\omega-3$ fatty acids is more effective in reaching the brain and achieving neuroprotection in an animal model of PD $[69,70]$.

$\omega-3$ fatty acids modulate brain growth and development, and neuronal differentiation. In addition, their ability to form an important constituent of neuronal cell membranes and involvement in memory formation and consolidation [71], explaining the beneficial action of EPA and DHA in the prevention and treatment of dementia and Alzheimer's disease [72,73]. However, different conclusion on DHA and EPA in neurological conditions had been present. Bate et al reported that pre-treatment with DHA or EPA significantly reduced the survival of cortical or cerebellar neurons, they noted that treatment with DHA or EPA reduced the free cholesterol content of neuronal membranes that increased the kinetics of incorporation $[74,75]$. These observations indicate that under some specific conditions $\omega-3$ fatty acids (EPA and DHA) may actually accelerate neuronal loss in the terminal stages of prion or Alzheimer's diseases. Our dates not show adverse effect on neurological conditions.

Higher expression of Olfactory receptor, SEPTIN5 in transgenic cattle may strengthen the function of olfactory sense, visual sense respectively $[76,77]$. Suh $M$ had demonstrated that fat- 1 mice enriched highly $\omega-3$ fatty acids in the retina lead to supernormal scotopic and photopic ERGs and increases in Muller cell reactivity and oxidative stress in photoreceptors [78].

\section{$\omega-3$ fatty acids on fertility}

PUFA composition of the cell membranes of the sperm and oocyte is important during fertilization [79]. Altering the PUFA sources in the diet resulted in concomitant changes in the $\omega-6$ and $\omega-3$ composition of sperm [80]. With regard to male fertility, PUFAs are essential by virtue of their ability to confer upon the sperm plasma membrane the fluidity it needs to achieve fertilization. Experiments on chickens have shown that feeding more PUFAs in the diet reduced the antioxidant status and quality of the semen [81].
Loss of the Calmegin (CLGN) lead to the production of sterile sperm that do not bind to the egg zone pellucida [82], so higher expression of CLNG in transgenic cattle might benefit to the spermatogenesis. EF-hand calcium binding domain 6 (EFCAB6) recruits histonedeacetylase complexes in order to repress transcription activity of androgen receptor (AR). The AR is a member of the nuclear receptor superfamily and plays a role as a ligand-dependent transcription factor. After a ligand binds to the AR, the AR is translocated into the nucleus and binds to the androgen-responsive element (ARE), on the androgen-activating gene that affects development, growth, and regulation of male reproductive functions $[83,84]$. Lower expression of EFCAB6 in transgenic cattle may lessen the suppression of AR and to express male-specific genes and the fertilization function of mature sperm.

Sex determining region $\mathrm{Y}$-box 8 (SOX8) is expressed in the developing testis around the time of sex determination suggesting that it might play a role in regulating the expression of testis-specific genes [85], higher expression of SOX8 in transgenic cattle may receptor the sex determination.

\section{Conclusion}

To study the effect of $\omega-3$ fatty acids on various physiological processes and pathologic situations, traditional approach to modify tissue nutrient composition is by supplementing the experimental groups with different $\omega-3 / \omega-6$ fatty acid ratios. Although this is an accepted mode of studying the effect, it is difficult to make all the dietary components identical. The inevitable differences between diets and their components, even if small they may be, may confound the study and contribute to inconsistencies or conflicting results observed. In these studies, fish oils or plant oils are used to provide the required $\omega-3 / \omega-6$ fatty acids in generally. Since these fatty acids are derived from different sources and are likely to contain other bioactive compounds, however minor they might be, are likely to affect the study outcomes. It is necessary to develop a transgenic animal model more efficient converting $\omega-6$ to $\omega-3$ fatty acids, the results obtained in such model will be more reliable to interpret the function of $\omega-3$ fatty acids.

Our data derived from the fat- 1 transgenic cattle support the notion that a reduced ratio of $\omega-6 / \omega-3$ fatty acids is favorable for normal cell function and may reduce the risk of certain diseases, such as cardiovascular disease, inflammatory disorders and cancer. Our result is generally consistent with studies using this model to address the effects of $\omega-3$ fatty acids. However, we detected some gene expression are contrary to previous studies, for instance, the production of VCAM-1 
from cultured endothelial cells is suppressed by $n-3$ PUFA, however, our date showed that expression of VCAM-1 in transgenic cattle is higher than wild-type cattle. In addition, the expression of WC1, ASMT and SOX8 were down-regulated and HIP1 expression was increased.

Due to the only three positive fat- 1 transgenic cattle detected, the result of cDNA microarray is limited by the little number of samples. It is necessary to verify the conclusion using large-scale samples when transgenic cattle have generation.

\section{Acknowledgements}

This work was supported by grant number 2008zx08007-002 form National transgenic project.

\section{Author details}

'Department of Animal Science, Tianjin Agriculture University, Tianjin 300384 China. ${ }^{2}$ College of Animal Science, Inner Mongolia Agriculture University, Hohhot 010018, China.

\section{Authors' contributions}

TG conceived and designed the study, carried out the experiments and wrote the manuscript. XF and XB helped to take samples. YW and FF participated in analysis data. YJ and HG participated in its design and coordination. All authors read and approved the final manuscript.

\section{Competing interests}

The authors declare that they have no competing interests.

Received: 1 December 2011 Accepted: 29 December 2011

Published: 29 December 2011

\section{References}

1. Kang ZB, Ge Y, Chen Z, Cluette-Brown J, Laposata M, Leaf A, Kang JX: Adenoviral gene transfer of Caenorhabditis elegans n-3 fatty acid desaturase optimizes fatty acid composition in mammalian cells. Proc Natl Acad Sci USA 2001, 98(7):4050-4054

2. Das NUndurti, Puskás GLászló: Transgenic fat-1 mouse as a model to study the pathophysiology of cardiovascular, neurological and psychiatric disorders. Lipids in Health and Disease 2009, 8:61.

3. Greenwald P, Sherwood K, McDonald SS: Fat caloric intake and obesity: lifestyle risk factors for breast cancer. J Am Diet Assoc 1997, 97:S24-30.

4. Harris WS, Lu GP, Rambjor GS, Wålen Al, Ontko JA, Cheng Q, Windsor SL: Influence of $n-3$ fatty acid supplementation on the endogenous activities of plasma lipoprotein lipase. Am J Clin Nutr 1997, 66:254-60.

5. Hodis HN, Mack WJ, Azen SP, Alaupovic P, Pogoda JM, LaBree L, Hemphill LC, Kramsch DM, Blankenhorn DH: Triglyceride and cholesterolrich lipoproteins have a differential effect on mild/moderate and severe lesion progression as assessed by quantitative coronary angiography in a controlled trial of lovastatin. Circulation 1994, 90:42-49.

6. Kitajka K, Puskás LG, Zvara A, Hackler L Jr, Barceló-Coblijn G, Yeo YK, Farkas T: The role of $n-3$ polyunsaturated fatty acids in brain: Modulation of rat brain gene expression by dietary $\mathrm{n}-3$ fatty acids. Proc Natl Acad Sci USA 2002, 99(5):2619-2624.

7. Clarke SD: Polyunsaturated fatty acid regulation of gene transcription: a mechanism to improve energy balance and insulin resistance. $\mathrm{Br} J$ Nutr 2000, 83(Suppl 1):S59-S66.

8. Jump DB: Dietary polyunsaturated fatty acids and regulation of gene transcription. Curr Opin Lipidol 2002, 13:155-164.

9. Clarke SD, Gasperikova D, Nelson C, Lapillonne A, Heird WC: Fatty acid regulation of gene expression: a genomic explanation for the benefits of the Mediterranean diet. Ann NY Acad Sci 2002, 967:283-298.

10. Grundy SM, Denke MA: Dietary influence on serum lipids and lipoproteins. J Lipid Res 1990, 31:1149-72.
11. Smith BK, Holloway GP, Reza-Lopez S, Jeram SM, Kang JX, Ma DW: A decreased $n-6 / n-3$ ratio in the fat- 1 mouse is associated with improved glucose tolerance. Appl Physiol Nutr Metab 2010, 35(5):699-706.

12. Kelly DE, Goodpaster B, Wing RR, Simoneau JA: Skeletal muscle fatty acid metabolism in association with insulin resistance, obesity and weight loss. Am J Physiol 1999, 277(6 pt.1):E1130-E1141.

13. Holloway GP, Thrush AB, heigenhauser GJ, Tandon NN, Dyck DJ, Bonen A, Spriet LL: Skeletal muscle mitochondrial fat/CD36 content and palmitate oxidation are not decreased in obese women. Am J Physiol Endocrinol Metab 2007, 292(6):1782-89.

14. Bruce CR, Hoy AJ, Turner N, Watt MJ, Allen TL, Carpenter K, Cooney GJ, Febbraio MA, Kraegen EW: Overexpression of carnitine palmitoyltransferase-1 in skeletal muscle is sufficient to enhance fatty acid oxidation and improve high-fat diet-induce insulin resistance. Diabetes 2009, 58(3):550-558.

15. Benton CR, Nickerson JG, Lally J, Han XX, Holloway GP, Glatz JF, Luiken JJ, Graham TE, Heikkila JJ, Bonen A: Modest PGC-1a overexpression in muscle in vivo is sufficient to increase insulin sensitivity and palmitate oxidation in subsarcolemmal, not intermyofibrillar, mitochondria. $J$ Biol Chem 2008, 283(7):4228-4240.

16. Rustan AC, Nossen JO, Christiansen EN, Drevon CA: Eicosapentaenoic acid decreases hepatic synthesis and secretion of triacylglycerol by decreasing the activity of acyl CoA: 1,2-diacylglycerol acyl transferase. J Lipid Res 1988, 29:1417-26.

17. Hertz R, Bishara SJ, Bar TJ: Mode of action of peroxisome proliferators as hypolipidemic drugs. J Biol Chem 1995, 270:13470-75.

18. Hertz R, Magenheim J, Berman I, Bar-Tana J: Fatty acid-CoA thioesters are ligands of hepatic nuclear factor-4. Nature 1998, 392:512-16.

19. Grimm H, Mayer K, Mayser P, Eigenbrodt E: Regulatory potential of $n-3$ fatty acids in immunological and inflammatory processes. Br J Nutr 2002, 87(Suppl 1):S59-S67.

20. Calder PC, Bevan SJ, Newsholme EA: The inhibition of T-lymphocyte proliferation is via an eicosanoid-independent mechanism. Immunology 1992, 75:108-115.

21. Zou GM, Tam YK: Cytokines in the generation and maturation of dendritic cells: Recent advances. Eur Cytokine Netw 2002, 13:186-199.

22. Akagawa KS, Komuro I, Kanazawa H, Yamazaki T, Mochida K, Kishi F: Functional heterogeneity of colony-stimulating factor-induced human monocyte-derived macrophages. Respirology 2006, 11(Suppl):S32-S36

23. Conti L, Cardone M, Varano B, Puddu P, Belardelli F, Gessani S: Role of the cytokine environment and cytokine receptor expression on the generation of functionally distinct dendritic cells from human monocytes. Eur J Immunol 2008, 38:750-762.

24. Arpaia E, Shahar M, Dadi H, Cohen A, Roifman CM: Defective T cell receptor signaling and $\mathrm{CD} 8^{+}$thymic selection in humans lacking ZAP-70 kinase. Cell 1994, 76:947-958.

25. Chan AC, Kadlecek TA, Elder ME, Filipovich AH, Kuo WL, Iwashima M, Parslow TG, Weiss A: ZAP-70 deficiency in an autosomal recessive form of severe combined immunodeficiency. Science 1994, 264:1599-1601.

26. Elder ME, Lin D, Clever J, Chan AC, Hope TJ, Weiss A, Parslow TG: Human severe combined immunodeficiency due to a defect in ZAP-70, a T cell tyrosine kinase. Science 1994, 264:1596-1599.

27. Negishi I, Motoyama N, Nakayama K, Nakayama K, Senju S, Hatakeyama S, Zhang Q, Chan AC, Loh DY: Essential role for ZAP-70 in both positive and negative selection of thymocytes. Nature 1995, 376:435-438.

28. Hatada MH, Lu X, Laird ER, Green J, Morgenstern JP, Lou M, Marr CS, Phillips TB, Ram MK, Theriault K: Molecular basis for interaction of the protein-tyrosine kinase ZAP-70 with the T-cell receptor. Nature 1995, 377:32-38.

29. Whisler RL, Chen M, Liu B, Newhouse YG: Age-related impairments in TCR/ CD3 activation of ZAP-70 are associated with reduced tyrosine phosphorylations of zeta-chains and p59fyn/p56lck in human T cells. Mech Ageing Dev 1999, 111(1):49-66.

30. Mellor AL, Munn DH: Tryptophan catabolism and T-cell tolerance: immunosuppression by starvation? Immunol 1999, 20:469-473.

31. Hwu P, Du MX, Lapointe R, Do M, Taylor MW, Young HA: Indoleamine 2,3dioxygenase production by human dendritic cells results in the inhibition of T cell proliferation. J Immunol 2000, 164:3596-3599.

32. Frumento $G$, Rotondo $R$, Tonetti M, Ferrara GB: $T$ cell proliferation is blocked by indoleamine 2,3-dioxygenase. Transplant Proc 2001, 33:428-430. 
33. Munn DH, Shafizadeh E, Attwood JT, Bondarev I, Pashine A, Mellor AL: Inhibition of T cell proliferation by macrophage tryptophan catabolism. $J$ Exp Med 1999, 189:1363-1372.

34. Okragly AJ, Hanby-Flarida M, Baldwin CL: Monocytes control gamma/delta T-cell responses by a secreted product. Immunology 1995, 86:599-605.

35. Mochida-Nishimura K, Akagawa KS, Rich EA: Interleukin-10 contributes development of macrophage suppressor activities by macrophage colony-stimulating factor, but not by granulocyte macrophage colonystimulating factor. Cell Immunol 2001, 214:81-88.

36. Hoek A, Rutten VP, Kool J, Arkesteijn GJ, Bouwstra RJ, Van Rhijn I, Koets AP: Subpopulations of bovineWC ${ }^{+} \gamma \delta \mathrm{T}$ cells rather than $\mathrm{CD} 4^{+} \mathrm{CD} 25^{\text {high }} \mathrm{Foxp}^{3}$ ${ }^{+}$T cells act as immune regulatory cells ex vivo. Vet Res 2009, 40:06.

37. Camisaschi C, Casati C, Rini F: LAG-3 expression defines a subset of CD4 $4^{(+)}$ $\mathrm{CD}_{2} 5^{(\mathrm{high})} \mathrm{Foxp}^{(+)}$regulatory T cells that are expanded at tumor sites. J Immunol 2010, 184(11):6545-51.

38. Reiter RJ, Acuña-Castroviejo D, Tan DX, Burkhardt S: Free radical-mediated molecular damage. Mechanisms for the protective actions of melatonin in the central nervous system. Ann N Y Acad Sci 2001, 939:200-15.

39. Saper CB, Scammell TE, Lu J: Hypothalamic regulation of sleep and circadian rhythms. Nature 2005, 437:1257-63.

40. Peterson LD, Thies F, Sanderson P, Newsholme EA, Calder PC: Low levels of eicosapentaenoic and docosahexaenoic acids mimic the effects of fish oil upon rat lymphocytes. Life Sci 1998, 62(24):2209-17.

41. Clinton SK, Giovannucci E: Diet, nutrition, and prostate cancer. Annu Rev Nutr 1998, 18:413-40

42. Harris WS, Lu GP, Rambjor GS, Walen Al, Ontko JA, Cheng Q, Windsor SL: Influence of $\mathrm{n}-3$ fatty acid supplementation on the endogenous activities of plasma lipoprotein lipase. Am J Clin Nutr 1997, 66:254-60.

43. Kolonel LN: Fat cancer: the epidemiological evidence in perspective. Adv Exp Biol Med 1997, 422:1-19.

44. Ross R: The pathogenesis of atherosclerosis: a perspective for the 1990s. Nature 1993, 362:801-9.

45. De CR, Bernini W, Carluccio MA, Liao JK, Libby P: Structural requirements for inhibition of cytokine-induced endothelial activation by unsaturated fatty acids. J Lipid Res 1998, 39:1062-70.

46. Munro JM: Endothelial-leukocyte adhesive interactions in inflammatory diseases. European Heart Journal 1993, 14:72S-77S.

47. Tapiero H, Ba GN, Couvreur P, Tew KD: Polyunsaturated fatty acids (PUFA) and eicosanoids in human health and pathologies. Biomed Pharmacother 2002, 56:215-222.

48. Narayanan BA, Narayanan NK, Reddy BS: Docosahexaenoic acid regulated genes and transcription factors inducing apoptosis in human colon cancer cells. Int J Oncol 2001, 19:1255-1262.

49. Ambs S, Merriam WG, Bennett WP, Felley-Bosco E, Ogunfusika MO, Oser SM, Klein S, Shields PG, Billiar TR, Harris CC: Frequent nitric oxide synthase-2expression in human colon adenomas: implication for tumor angiogenesis in colon cancer progression. Cancer Res 1998, 58:334-341.

50. Jaiswal M, LaRusso NF, Burgart L, Gores GJ: Inflammatory citokines induce DNA damage and inhibit DNA repair in colonic carcinoma cells by a nitric oxide dependent mechanism. Cancer Res 2000, 60:184-189.

51. Narayanan BA, Narayanan NK, Simi B, Reddy BS: Modulation of inducible nitric oxide synthase and related proinflammatory genes by the omega3 fatty acid docosahexaenoic acid in human colon cancer cells. Cancer Res 2003, 63:972-979.

52. Musiek ES, Brooks JD, Joo M, Brunoldi E, Porta A, Zanoni G, Vidari G, Blackwell TS, Montine TJ, Milne GL, McLaughlin B, Morrow JD: Electrophilic cyclopentenone neuroprostanes are antiinflammatory mediators formed from the peroxidation of the omega-3 polyunsaturated fatty acid docosahexaenoic acid. J Biol Chem 2008, 283:19927-19935.

53. Musiek ES, Gao L, Milne GL, Han W, Everhart MB, Wang D, Backlund MG, DuBois RN, Zanoni G, Vidari G, Blackwell TS, Morrow JD: Cyclopentenone isoprostanes inhibit the inflammatory response in macrophages. $J$ Biol Chem 2005, 280:35562-35570.

54. Berger A, Mutch DM, German JB, Roberts MA: Unraveling lipid metabolism with microarrays: effects of arachidonate and docosahexaenoate acid on murine hepatic and hippocampal gene expression. Genome Biol 2002, 3(7), preprint0004.

55. Wang X, Wang Y, Yu L: CSPG4 in Cancer: Multiple Roles. J Lipid Res 2011, 52(2):263-71.
56. Xia S, Lu Y, Wang J, He C, Hong S, Serhan CN, Kang JX: Melanoma growth is reduced in fat- 1 transgenic mice: impact of omega-6/omega-3 essential fatty acids. Proc Natl Acad Sci 2006, 103(33):12499-504.

57. Weylandt KH, Krause LF, Gomolka B, Chiu CY, Bilal S, Nadolny A, Waechter SF, Fischer A, Rothe M, Kang JX: Suppressed liver tumorigenesis in fat-1 mice with elevated omega-3 fatty acids is associated with increased omega- 3 derived lipid mediators and reduced TNF- $a$ Carcinogenesis 2011, 32(6):897-903.

58. Mayer K, Kiessling A, Ott J, Schaefer MB, Hecker M, Henneke I, Schulz R, Günther A, Wang J, Wu L, Roth J, Seeger W, Kang JX: Acute lung injury is reduced in fat- 1 mice endogenously synthesizing $n-3$ fatty acids. Am J Respir Crit Care Med 2009, 179(6):474-83.

59. Jia Q, Lupton JR, Smith R, Weeks BR, Callaway E, Davidson LA, Kim W, Fan YY, Yang P, Newman RA, Kang JX, McMurray DN, Chapkin RS: Reduced colitis-associated colon cancer in Fat-1 ( $\mathrm{n}-3$ fatty acid desaturase) transgenic mice. Cancer Res 2008, 68(10):3985-91.

60. Shin AC, Steven JK, Kwang CC: Huntingtin-interacting protein 1-mediated neuronal cell death occurs through intrinsic apoptotic pathways and mitochondrial alterations. FEBS Lett 2006, 80(22):5275-82.

61. Rao DS, Hyun TS, Kumar PD, Mizukami IF, Rubin MA, Lucas PC, Sanda MG, Ross TS: Huntingtin-interacting protein 1 is overexpressed in prostate and colon cancer and is critical for cellular survival. J Clin Invest 2002, 110:351-360

62. Das UN: Folic acid and polyunsaturated fatty acids improve cognitive function and prevent depression, dementia, and Alzheimer's diseasebut how and why? Prostaglandins Leukot. Essent Fatty Acids 2008, 78:11-19.

63. Lukiw WJ, Cui JG, Marcheselli VL, Bodker M, Botkjaer A, Gotlinger K, Serhan CN, Bazan NG: A role for docosahexaenoic acidderived neuroprotectin D1 in neural cell survival and Alzheimer disease. J Clin Invest 2005, 115:2774-2783.

64. Calon F, Lim GP, Morihara T, Yang F, Ubeda O, Salem N Jr, Frautschy SA, Cole GM: Dietary $n-3$ polyunsaturated fatty acid depletion activates caspases and decreases NMDA receptors in the brain of a transgenic mouse model of Alzheimer's. Eur J Neurosci 2005, 22:617-626.

65. Wu Q, Maniatis T: A striking organization of a large family of human neural cadherin-like cell adhesion genes. Cell 1999, 97(6):779-90.

66. Huang D, Yu B: Recent advance and possible future in TREK-2: a twopore potassium channel may involved in the process of NPP, brain ischemia and memory impairment. Med Hypotheses 2008, 70(3):618-24.

67. O'Connor TP, Cockburn K, Wang W, Tapia L, Currie E, Bamji SX: Semaphorin $5 B$ mediates synapse elimination in hippocampal neurons. Neural Development 2009, 4:18.

68. He C, Qu X, Cui L, Wang J, Kang JX: Improved spatial learning performance of fat- 1 mice is associated with enhanced neurogenesis and neuritogenesis by docosahexaenoic acid. Proc Natl Acad Sci 2009, 106(27):11370-11375

69. Ménesi D, Kitajka K, Molnár E, Kis Z, Belleger J, Narce M, Kang JX, Puskás LG, Das UN: Gene and protein expression profiling of the fat- 1 mouse brain. Prostaglandins Leukot Essent Fatty Acids 2009, 80(1):33-42.

70. Bousquet M, Gue K, Emond V, Julien P, Kang JX, Cicchetti F, Calon F: Transgenic conversion of omega- 6 into omega- 3 fatty acids in a mouse model of Parkinson's disease. J Lipid Res 2011, 52(2):263-71.

71. Calderon F, Kim HY: Docosahexaenoic acid promotes neurite growth in hippocampal neurons. J Neurochem 2004, 90(4):979-88.

72. Akbar M, Calderon F, Wen Z, Kim HY: Docosahexaenoic acid: a positive modulator of Akt signaling in neuronal survival. Proc Natl Acad Sci 2005 , 102:10858-10863.

73. Hashimoto M, Tanabe Y, Fujii Y, Kikuta T, Shibata H, Shido O: Chronic administration of docosahexaenoic acid ameliorates the impairment of spatial cognition learning ability in amyloid beta-infused rats. J Nutr 2005, 135:549-555.

74. Bate C, Marshall V, Colombo L, Diomede L, Salmona M, Williams A: Docosahexaenoic and eicosapentaenoic acids increase neuronal death in response to HuPrP82-146 and Abeta 1-42. Neuropharmacology 2008, 54:934-943.

75. Bate C, Tayebi M, Diomede L, Salmona M, Williams A: Docosahexaenoic and eicosapentaenoic acids increase prion formation in neuronal cells. BMC Biol 2008, 6:39. 
76. Malnic B, Godfrey PA, Buck LB: The human olfactory receptor gene family. Proc Natl Acad Sci 2004, 101(8):2584-9.

77. Xin X, Pache M, Zieger B, Bartsch I, Prünte C, Flammer J, Meyer P: Septin expression in proliferative retinal membranes. J Histochem Cytochem 2007, 55(11):1089-94.

78. Suh $M$, Sauvé Y, Merrells KJ, Kang JX, Ma DW: Supranormal electroretinogram in fat-1 mice with retinas enriched in docosahexaenoic acid and $n-3$ very long chain fatty acids (C24-C36). Invest Ophthalmol Vis Sci 2009, 50(9):4394-401.

79. Aitken RJ, Baker HW: Seminal leukocytes: passengers, terrorists or good samaritans? Hum Reprod 1995, 10:1736-1739.

80. Maldjian A, Pizzi F, Gliozzi T, Cerolini S, Penny P, Noble R: Changes in sperm quality and lipid composition during cryopreservation of boar semen. Theriogenology 2005, 63:411-421.

81. Zanini SF, Torres CA, Bragagnolo N, Turatti JM, Silva MG, Zanini MS: Evaluation of the ratio of omega-6: omega-3 fatty acids and vitamin $E$ levels in the diet on the reproductive performance of cockerels. Arch Tierernahr 2003, 57:429-442.

82. Ikawa M, Nakanishi T, Yamada S, Wada I, Kominami K, Tanaka H, Nozaki M, Nishimune Y, Okabe M: Calmegin is required for fertilin alpha/beta heterodimerization and sperm fertility. Dev Biol 2001, 240(1):254-61.

83. McPhaul MJ, Marcelli M, Zoppi S, Griffin JE, Wilson JD: Genetic basis of endocrine disease 4 . The spectrum of mutations in the androgen receptor gene that causes androgen resistance. J Clin Endocrinol Metab 1993, 76:17-23.

84. Yong EL, Ghadessy F, Wang Q, Mifsud A, Ng SC: Androgen receptor transactivation domain and control of spermatogenesis. Rev Reprod 1998, 3:141-144.

85. Schepers G, Wilson M, Wilhelm D, Koopman P: SOX8 is expressed during testis differentiation in mice and synergizes with SF1 to activate the Amh promoter in vitro. J Biol Chem 2003, 278(30):28101-8.

doi:10.1186/1476-511X-10-244

Cite this article as: Guo et al: Fat-1 transgenic cattle as a model to study the function of $\omega-3$ fatty acids. Lipids in Health and Disease 2011 10:244.

\section{Submit your next manuscript to BioMed Central and take full advantage of:}

- Convenient online submission

- Thorough peer review

- No space constraints or color figure charges

- Immediate publication on acceptance

- Inclusion in PubMed, CAS, Scopus and Google Scholar

- Research which is freely available for redistribution

Submit your manuscript at www.biomedcentral.com/submit 